corporate," whilst they, its mere shadow, most presumptuously assume the responsibility of electing one of themselves as the representative of the Royal College of Surgeons of England in the General Medical Council, I have no hesitation in stating my willingness to stand foremost in the rank for this desirable purpose. And I have not the least doubt myself as to the ultimate issue of a legal decision; for if words mean anything at all, the charter of 1852 is dead against them, for, as you have already justly observed, "it recognises distinctly the Fellows and Members as constituent parts of the corporation, and nowhere gives the Council separate jurisdiction." Now that we are in earnest in preparing for this legal struggle, I hope the Council will at once admit the necessity of gracefully acceding to us that which we shall legally wring from them as a right, and thus avoid all party feeling, and an unseemly deadly legal feud between 16,000 members of its "body corporate" and its Council of 25.

Permit me, Sir, to take this opportunity of replying to the many gentlemen who have written to me to know "When and what action" I intend to take relative to the election of councillors in July next. I have determined (encouraged by the great amount of support I am prom mised by the Fellows-yes, and Members too) to organise, and oust every retiring member of Council who will not pledge himself in writing to bring forward or support measures for the correcting of the defects and abuses complained of, in answer to a letter which I shall deem it my duty to address to these gentlemen as soon as I shall have official information as to who are the retiring members. We have plenty of new blood of the right material ready for the Council, and who will be nominated when the time comes.

If the Council still remain obdurate, we shall steadily persevere, although the process will be a slow one, until we have purged the Council of their many iniquities, not with " hyssop and honey," but with that never-failing national drastic, "public opinion," until the Royal College of Surgeons shall not only be one of the noblest, but one of the best managed corporate institutions in the world.

Fellows and members desirous of contributing to a fund for the defrayment of the necessary preliminary legal and other expenses, will please communicate with me at once. The amount I shall publish in THE LANCET, together with (or without, if desired) the names of the contributors. In the meanwhile, no time shall be lost in gathering up our legal armour to fight the great cause.

The whole of the chirurgical profession will readily endorse four remarks relative to the present representative of the Council, Mr. Cæsar Hawkins, than whom a better representative could not possibly be. It is not, however, of men, but of measures, we are complaining.

I am, \&c.

Spalding, March, 1869.

EDwiN Morris, M.D., F.R.C.S.

\section{THE NEW DUTIES OF WORKHOUSE MEDICAL OFFICERS.}

To the Editor of THE LANCET.

SIR,-Would you have the goodness to insert, in your next issue, the enclosed memorial, which will be presented to Mr. Goschen in some manner hereafter to be decided on?

It has already been adopted by upwards of 100 workhouse medical officers residing in the Southern or South-Western counties, to whom it has been sent, and if any gentleman desires to join his brethren in memorialising, he can do so, by making a copy, signing, and forwarding it as early as possible to me.

At the time of the issue of the order you commented with much deserved severity, upon the unfairness the Poorlaw Board had been guilty of in imposing these additional duties; but neither you nor the profession could have then imagined that the authors of the order contemplated the completion of their injustice by appointing their respective nephews to lucrative public appointments, the duties of which, in future, were to be performed almost entirely by workhouse medical officers, without any remuneration of any kind, and with the certainty of their being pretty generally embroiled with their local Boards, if the requirements contained therein were honestly complied with. I am, Sir, your obedient servant,

Dean-street, March 17th, 1869.

JOSEPH ROGERS.

To the Right Honourable the Poor-law Board.

My Lords and Gentlemen,-We, the undersigned, medical officers of workbouses, looking forward to the time when it will again become our duty to make the "statement" referred to in the General Order of your Board, dated April 4th, 1868, request to be supplied with an authoritative standard of requirements of your Board with respect to the several matters specified in the questions to be answered by us. We beg to express our desire that some other officers of the Guardians may be made responsible for supplying us with information on such matters as do not fall within the scope of our duties as medical attendants on the sick.

We wish to be informed whether our statement will be considered by your Board as private and confidential; whether it will be regarded as furnishing hints to guide and assist the official paid inspectors in the discharge of their duties; or whether it will be deemed public, accessible to Guardians, and liable to be sent to them by your Board. In the latter case, we beg to inquire how far we may expect the support of your Board, in the event of our "statement" bringing upon us the displeasure of our respective Guardians. And on this subject we desire to point out the grievous hardships inflicted on those workhouse medical officers who are not permanently appointed, in being called upon to make this "statement." Should they tone it down to avoid offending their Guardians, they will be liable to censure or dismissal at the hands of your Board for "neglect of duty;" should they, on the other hand, make a strictly true, but perhaps necessarily unfavourable "statement," they incur the risk of not being re-elected by their Guardians-that is, of dismissal without explanation, - and thus suffer stigma and injury for the faithful performance of their duty. We respectfully submit that this is not a position in which any officer should be placed.

Lastly, we beg that your Board will be pleased to direct suitable remuneration to be made to us for the new and responsible work imposed upon us by being called upon to perform the highly important duties of the inspectors, added to our already onerous and ill-paid labour as medical officers. We have the honour to be, \&c.

\section{THE POOR-LAW BOARD AND THE HOLBORN BOARD OF GUARDIANS.}

The Poor-law Board have addressed a letter to the Guardians of the Holborn Union, intimating that it is not their intention to proceed with the Finsbury Sick Asylum. They propose to unite the Holborn Union with St. Luke's and St. James's (Clerkenwell), to form one Poor-law Union for all purposes. We must, however, emphatically protest against the appropriation of St. Luke's Workhouse as an infirmary. The site is, no doubt, excellent, but the building is ill arranged, the rooms are low, dark, and generally ill ventilated,--in fact, totally unsuitable for any such purpose in their present form. On the whole, this concentration must be regarded as a most important step, the propriety of which can scarcely be determined on the moment.

\section{PREVENTION OF CONTAGIOUS DISEASES.}

Av important meeting was held at Birmingham on the 16 th inst. to discuss the propriety of applying the Contagious Diseases Act to that town. There were present the Bishop of Worcester and the majority of the beneficed clergy, with many leading medical men, amongst whom were Dr. Birt Davies, Mr. Furneaux Jordan, Dr. Bracey, and Dr. Bartleet, besides a large number of the leading townspeople of Birmingham. Mr. Bracey, the hon. secretary, read a report, which showed that contagious disease is very prevalent in Birmingham. At the Queen's-Hospital, during eleven consecutive weeks, Mr. Wilders found 38 per cent. of his 